\title{
IMPACT OF USE OF CHEMICAL TRANSFORMATION MODULES IN CALPUFF ON THE RESULTS OF AIR DISPERSION MODELLING
}

\author{
WPLYW ZASTOSOWANIA MODUŁÓW PRZEMIAN CHEMICZNYCH \\ W MODELU CALPUFF NA WYNIKI MODELOWANIA \\ DYSPERSJI ZANIECZYSZCZEŃ W POWIETRZU
}

\begin{abstract}
Assessment of the impact on air quality for combustion sources should be carried out using advanced modelling systems with chemical transformation modules taken into account, especially for the facilities characterized by significant emission of gaseous air pollutants (including $\mathrm{SO}_{2}$ ). This approach increases the reliability of the obtained evaluation results by modelling the formation of secondary inorganic aerosol (SIA) in the air which can substantially contribute to PM10. This paper assesses in this regard selected chemical transformation modules (MESOPUFF, RIVAD/ARM3, ISORROPIA/RIVAD) available in the CALPUFF model (v. 6.42) and its application in the atmospheric dispersion modelling of air emissions from a coal-fired large combustion plant (LCP) not equipped with a flue gas desulphurization (FGD) system. It has been proven that consideration an additional mechanism of secondary sulfate aerosol formation in aqueous phase in the ISORROPIA/RIVAD module (AQUA option) causes a significant increase in the annual average concentration of PM10 in the air compared to the other considered options, along with the calculation variant which excludes chemical transformation mechanisms. Type of the selected chemical transformation module has no significant effect on the results of modelled $\mathrm{NO}, \mathrm{NO}_{2}$ and $\mathrm{NO}_{\mathrm{x}}$ concentrations in the air. However, it can lead to different $\mathrm{SO}_{2}$ results, especially for annual averaged, and in some points, for the hourly averaged concentrations.
\end{abstract}

Keywords: air pollution modelling, CALPUFF, atmospheric chemical transformations, secondary inorganic aerosols, large combustion plants

\section{Introduction}

Evaluation of the impact on air quality is usually done using simplified, stationary dispersion models that do not take into account chemical transformations of pollutants taking place in the atmospheric air or treat these transformations in a simplified manner. The latter can include models such as, e.g. OCDM [1], CTDMPLUS [2, 3], ISC3 [4], AUSTAL [5], AERMOD [6, 7], OML [8] or ADMS [9]. Increasingly non-stationary models capable of simulating the effects of time- and space-varying meteorological conditions and allowing for inclusion of more advanced modules of chemical

\footnotetext{
${ }^{1}$ AGH University of Science and Technology, Department of Environmental Management and Protection, al. A. Mickiewicza 30, 30-059 Kraków, Poland, phone +48 1261745 03, fax +48 126175066

*Corresponding author: oleniacz@agh.edu.pl
} 
transformations are used to perform more complex modelling of atmospheric dispersion in mesoscale [10]. Among them the most popular are: CALMET/CALPUFF [11-15], as well as UAM-V, MCCM, WRF/Chem, CAMx and CMAQ [16-19]. However, these models are characterized by high requirements associated with the preparation of input data and long calculation time.

Particularly noteworthy is the CALMET/CALPUFF modelling system recommended by the US Environmental Protection Agency for the calculations of atmospheric pollutant dispersion in long range transport (>50 km) [20], but it can also be used on a smaller scale when the analysed area is characterized by complex terrain, and variable in its space meteorological conditions [21]. It is possible to use this system to assess the impact of emissions sources on air quality taking into account the available modules of chemical transformations leading inter alia to the formation of secondary inorganic aerosol (SIA). This allows for a more accurate reflection of air pollutant concentrations which are subject to chemical transformations in the atmosphere or are formed as a result of this type of transformations.

This paper presents the consequences related to the execution of the air quality impact assessment for a large combustion plant in a near-field relatively complex terrain, using a variety of chemical transformation modules available in the CALPUFF model v. 6.42. The results of this assessment were compared with the results of calculations obtained without taking into account of these modules, and the results of measurements of pollutant concentrations at air quality monitoring stations.

Earlier studies evaluating the CALPUFF model [22-26] mainly focused on validation and adjustment of the input settings of the model and used an older version of this model which did not include the latest updates for the chemical transformation modules or the atmospheric chemistry option was turned off. There are also known new works that compare - in this respect - the CALPUFF model with other models [27-32] or evaluate the application of the CALPUFF model in an urban scale including secondary sulphate and nitrate aerosols [33]. Some of the studies were related to atmospheric dispersion modelling of air pollutants emitted from large combustion plants [22, 23, 26, 27, 34-37], but if their authors took into account the mechanisms of chemical transformations, it was only those that existed within the modules: MESOPUFF (MESOPUFF II) or RIVAD/ARM3.

\section{Material and methods}

\section{Characteristics of the object of the research}

The object of the research was the large combustion plant (LCP) located in Poland, a few kilometers from the Krakow city center. The location of this object within the city, and the location of Krakow in the Malopolska voivodship is shown in Figure 1. The LCP runs a combined production of heat and power (CHP) using coal as the main fuel. This CHP Plant represents one of the largest industrial sources of dust and gas emissions located within the city of Krakow [38, 39]. On its premises, four cogeneration steam boilers and three hot water boilers are operated with a total installed capacity of $1118 \mathrm{MW}_{\mathrm{e}}$ and $460 \mathrm{MW}_{\mathrm{t}}$. For purposes of start-up and stabilization of the combustion process, these boilers are equipped with pressure oil burners with a centrifugal atomizer. Steam boilers are fired not only with pulverized coal but also solid biomass. In the analysed period (year 2012) exhaust gas cleaning system consisted of only electrostatic precipitators (one per boiler), while waste gases were discharged into the air by two stacks with a height of 
225 and 260 meters respectively. In 2012, the amount of burned coal, biomass, and heating oil amounted to: $734.2 ; 168$ and $1.3 \mathrm{Gg}$, and the total emission of total dust, sulphur dioxide $\left(\mathrm{SO}_{2}\right)$, and nitrogen oxides $\left(\mathrm{NO}_{\mathrm{x}}\right)$ as nitrogen dioxide $\left(\mathrm{NO}_{2}\right)$ reached: 700,6505 and $4178 \mathrm{Mg}$ respectively. Relatively high $\mathrm{SO}_{2}$ emissions are due to the lack of flue gas desulphurization plant (the FGD system for this facility was started up in 2015).

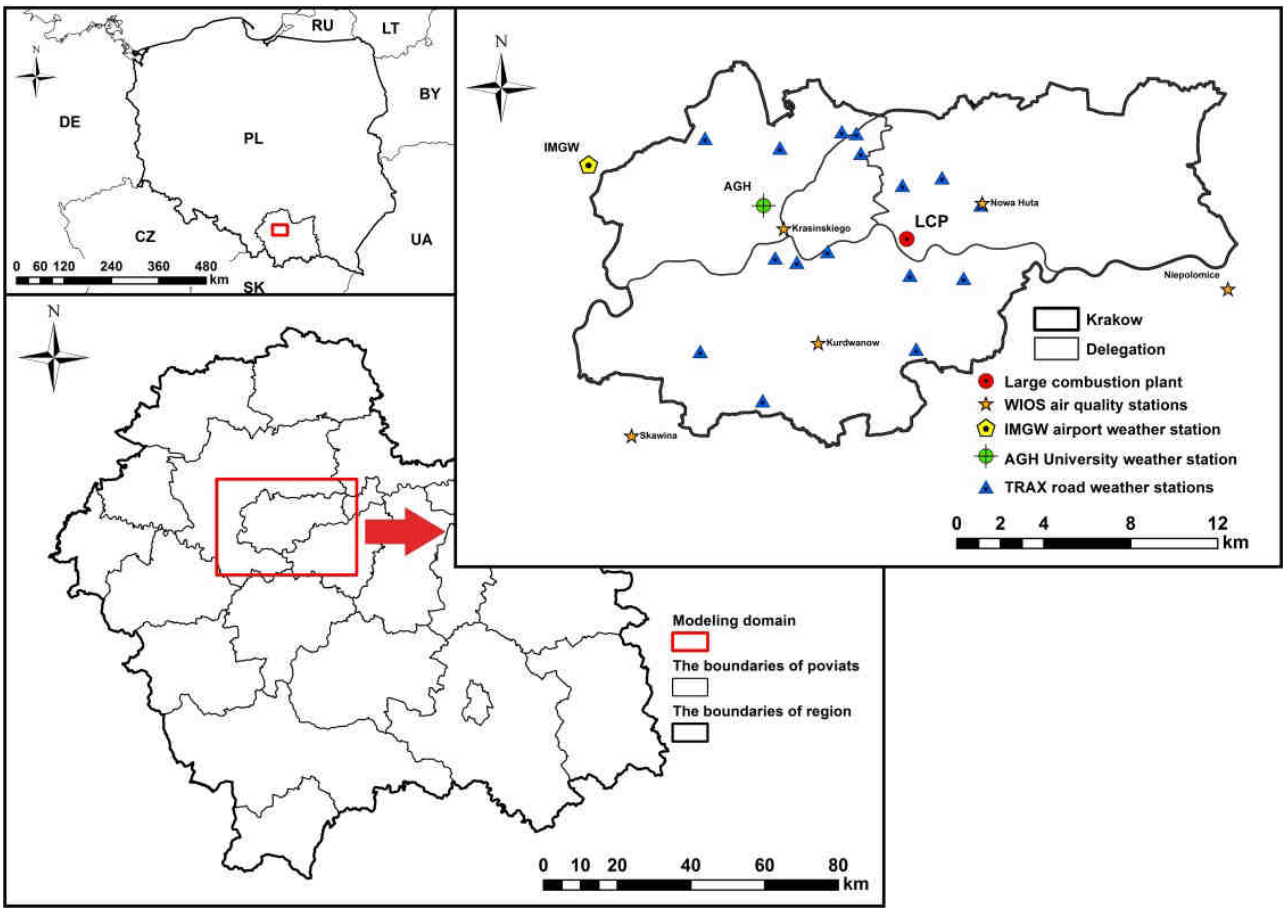

Fig. 1. Location of the computational domain, the object of the research (LCP), the weather stations, and the air quality monitoring stations

In the assessment of the impact on air quality conducted for the purposes of this study, actual data from the continuous emission monitoring system (emission of air pollutants, and flue gas parameters) for 2012 with 1-hour step was used. This assessment takes into account not only the situations related to the normal operation of the installation but also boiler start-up phases for which pollutant emissions were adopted on the basis of manual measurements. Due to the fact, that the mechanisms of the formation of SIA in atmospheric air take into account both the nitric oxide (NO), and nitrogen dioxide $\left(\mathrm{NO}_{2}\right)$, the emissions of these substances were evaluated based on the results of measurement of $\mathrm{NO}_{\mathrm{x}}$ emissions adopting their percentage shares at a 95 and 5\% respectively. Total dust grain fractions were determined on the basis of literature data [40].

\section{Methodology of calculations}

Modelling of atmospheric dispersion of pollutants was carried in a grid with a resolution of $200 \mathrm{~m}$ in the area of $38 \cdot 26 \mathrm{~km}$ covering the whole city of Krakow, and neighboring areas (Fig. 1). For many years in this region, PM10 air concentrations occur 
at levels greater than permissible limits [41-43]. Thus, in locations of air quality monitoring stations, extra calculation points were designated in order to evaluate the potential share of considered plant in the level of measured concentrations, and to determine the differences in this area arising from the application in the modelling process of selected chemical transformation modules.

Terrain and land cover data were obtained from SRTM3 and CLC2006 databases respectively. Spatial data was pre-treated in ArcGIS software and so called pre-processors of geophysical data (TERREL, MAKEGEO) in accordance with the procedure described inter alia in $[44,45]$. The results of the observation of meteorological parameters were obtained from multiple sources for the year 2012. A total of 18 surface stations located throughout the city of Krakow and its outskirts (Fig. 1), and 3 upper air stations (Poprad, Legionowo, Wroclaw) were used.

Variables in time and space, three-dimensional wind and temperature field, as well as two-dimensional field of the microclimate parameters necessary in the process of atmospheric dispersion modelling (PG stability class, mixing height, Monin-Obukhov length, friction velocity, convective velocity scale) were generated using CALMET diagnostic model [11].

The calculations of pollutant dispersion in ambient air were performed using a multi-layer, multi-species non-steady-state puff dispersion model CALPUFF (ver. 6.42) [12-15]. They were executed for five variants including disabled chemical transformation option (variant V1), and four scenarios with various modules of chemical transformation of SIA formation (variants V2-V5). These variants differed among themselves via the MCHEM option (selection of the chemical transformation module), and MAQCHEM option (use aqueous phase transformation module), and entered input data (Table 1).

In the absence of appropriate measuring data of $\mathrm{NH}_{3}$ and $\mathrm{H}_{2} \mathrm{O}_{2}$ air concentrations in Krakow, the background for these substances necessary in computing process was adopted on the basis of measurements available from other locations. Average monthly concentrations of $\mathrm{NH}_{3}$ were determined on the basis of data from the continuous monitoring carried out at urban background stations in various cities in Europe [42], and the average seasonal concentration of $\mathrm{H}_{2} \mathrm{O}_{2}$ was adopted based on a measurement campaign conducted in Wroclaw [38]. The calculations also included the background of ozone in the form of 1-hour concentrations recorded in 2012 at one of the air quality monitoring stations in Krakow (Kurdwanow urban background station).

Table 1

Characteristics of calculation variants in terms of used chemical transformation modules and corresponding settings, and input data

\begin{tabular}{|c|c|c|c|c|c|c|c|c|}
\hline \multirow[b]{2}{*}{ Variant } & \multicolumn{2}{|c|}{ Settings } & \multicolumn{3}{|c|}{ Background concentrations } & \multirow[b]{2}{*}{$\begin{array}{c}\mathrm{NO}_{\mathrm{x}} \\
\text { emission }\end{array}$} & \multirow{2}{*}{$\begin{array}{c}\text { Chemical } \\
\text { transformation } \\
\text { modules }\end{array}$} & \multirow[b]{2}{*}{ References } \\
\hline & MCHEM & $\begin{array}{l}\text { MAQ } \\
\text { CHEM }\end{array}$ & $\mathrm{NH}_{3}$ & $\mathrm{O}_{3}$ & $\mathrm{H}_{2} \mathrm{O}_{2}$ & & & \\
\hline V1 & 0 & 0 & - & - & - & $\mathrm{NO}_{\mathrm{x}}$ & - & - \\
\hline V2 & 1 & 0 & Month & 1-h & - & $\mathrm{NO}_{\mathrm{x}}$ & MESOPUFF & {$[46-48]$} \\
\hline $\mathrm{V} 3$ & 3 & 0 & Month & 1-h & - & $\mathrm{NO} / \mathrm{NO}_{2}$ & RIVAD/ARM3 & [49] \\
\hline V4 & 6 & 0 & Month & 1-h & - & $\mathrm{NO} / \mathrm{NO}_{2}$ & $\begin{array}{l}\text { ISORROPIA/ } \\
\text { RIVAD }\end{array}$ & \multirow{2}{*}{$\begin{array}{c}{[13,14,50,} \\
51]\end{array}$} \\
\hline V5 & 6 & 1 & Month & 1-h & Season & $\mathrm{NO} / \mathrm{NO}_{2}$ & $\begin{array}{c}\text { ISORROPIA/ } \\
\text { RIVAD+AQUA }\end{array}$ & \\
\hline
\end{tabular}


Calculations were performed for maximum 1-hour average concentrations, 24-hour average concentrations, and the annual average concentrations in the air of $\mathrm{NO}, \mathrm{NO}_{2}$ (and/or $\mathrm{NO}_{\mathrm{x}}$ ), $\mathrm{SO}_{2}$, primary particulate matter (PPM), secondary inorganic aerosols result from emission of $\mathrm{NO}_{\mathrm{x}}\left(\mathrm{NO}_{3}{ }^{-}\right)$and $\mathrm{SO}_{2}\left(\mathrm{SO}_{4}{ }^{2-}\right)$, and the sum of the secondary inorganic aerosol (SIA), as well as the sum of PPM and SIA including fractions below $10 \mu \mathrm{m}$ (PM10). Calculation results obtained for individual variants were subjected to a comparative analysis in order to determine the significance of the differences existing between considered options. In this analysis, particular attention has been paid to the location of the air quality monitoring station and the results of calculations of average annual concentrations.

\section{Description of considered chemical transformation modules}

The following modules were subjected to analysis: MESOPUFF, RIVAD/ARM3 and ISORROPIA/RIVAD, as well as the ISORROPIA/RIVAD+AQUA module with an enabled new mechanism of chemical transformations in the aqueous-phase changing the degree of transformation of $\mathrm{SO}_{2}$ to sulphates [13-15].

The MESOPUFF module (MCHEM = 1) is based on the MESOPUFF II model that utilizes a pseudo first order chemical reactions mechanism describing the conversion of $\mathrm{SO}_{2}$ into $\mathrm{SO}_{4}{ }^{2-}$, and $\mathrm{NO}_{\mathrm{x}}\left(\mathrm{NO}+\mathrm{NO}_{2}\right)$ into $\mathrm{NO}_{3}{ }^{-}$in ambient air [48]. It takes into account the space-time variability of environmental factors such as: concentration of ozone atmospheric stability class, relative humidity, total solar radiation intensity and the plume $\mathrm{NO}_{\mathrm{x}}$ concentrations. $\mathrm{SO}_{2}$ and $\mathrm{NO}_{\mathrm{x}}$ transformations in the night time in the gas phase are described by constant coefficients of conversion implemented in the module while the rate of aqueous-phase conversion of $\mathrm{SO}_{2}$ to sulphate is parameterized as a function of the relative humidity $[12,47]$. Heterogeneous reactions leading to the formation of sulphates are irreversible in contrast to the nitrates formation processes which are reversible because of the equilibrium which is established between nitric acid, ammonia, and ammonium nitrate. Thus, nitrates form unstable forms of aerosol in the air, the stability of which largely depends on local environmental factors and the local chemical composition of the atmosphere. Nitrates concentration in the air is primarily limited by availability of ammonia in the atmosphere which is effectively neutralized by the sulphates present in the atmosphere [48].

The RIVAD/ARM3 module (MCHEM = 3) assumes that the conversion processes of NO into $\mathrm{NO}_{2}$ and the $\mathrm{NO}_{2}$ into $\mathrm{NO}_{3}$ take place in equilibrium with gaseous $\mathrm{HNO}_{3}$ and $\mathrm{NH}_{4} \mathrm{NO}_{3}$ in aerosol form [49]. To determine the equilibrium between nitric acid and ammonia and ammonium nitrate the reaction mechanism implemented in the model MESOPUFF II is used [12]. In RIVAD condensed pseudo-first-order chemical scheme, the rate of sulphate and nitrate production in gas-phase is estimated by calculating concentration of hydroxyl radical, $\mathrm{OH}^{-}$. Hydroxyl radical is the primary oxidizer of $\mathrm{SO}_{2}$ and $\mathrm{NO}_{2}$. In the RIVAD model a constant speed of heterogeneous $\mathrm{SO}_{2}$ oxidation is equal to $0.2 \%$ per hour. This speed is added to the conversion speed of $\mathrm{SO}_{2}$ into $\mathrm{SO}_{4}{ }^{2-}$ in the gas-phase [12]. In the latest version of the RIVAD/ARM3 module used in the CALPUFF model v. 6.4 a correction of an error was introduced that caused the re-evaluation of concentrations of SIA formed during oxidation of $\mathrm{SO}_{2}$ and $\mathrm{NO}_{\mathrm{x}}$. The error was caused by lack of updates of $\mathrm{O}_{3}$ concentrations in the modelled plume. The problem has been solved by recording the history of $\mathrm{O}_{3}$ concentrations in the puff. The concentration of $\mathrm{O}_{3}$ in a given point in time is calculated as the weighted average of $\mathrm{O}_{3}$ concentrations in the puff from the 
previous time step, and the background ozone concentration. The adjustment of this error does not significantly change modelling results [13]. In addition to this adjustment, the oxidation processes of $\mathrm{SO}_{2}$ and $\mathrm{NO}_{2}$ by the hydroxyl radical $\left(\mathrm{OH}^{-}\right)$was optimized, so as to make it compatible with the levels used in modern photochemical and regional models (inter alia such as CMAQ). The RIVAD model assumes low background concentrations of volatile organic compounds (VOC), and is not suitable for carrying out the calculations for urban areas.

ISORROPIA is a model of chemical transformations based on an alternative - in relation to the MESOPUFF and RIVAD/ARM3 modules - mechanism of forming inorganic aerosol in air under thermodynamic equilibrium conditions [50, 51]. Currently it is also used in many of contemporary air quality forecasting models such as CMAQ, CAMx, CMAQ-Madrid, and REMSAD [13]. The ISORROPIA 2.1 model has been implemented in CALPUFF v. 6.4. In this model thermodynamic equilibrium between aerosol-gas phases is determined based on the activity of substances, and the stoichiometric coefficients of the substances involved in the reactions. The mechanism of the chemical reactions included 4 of gaseous substances, 15 liquid substances, and 19 substances in solid state (salts) [51]. The number of substances, and equilibrium reactions in the analysed mechanism is determined by the relative number of aerosol formation precursors $\left(\mathrm{NH}_{3}, \mathrm{Na}, \mathrm{Ca}, \mathrm{K}, \mathrm{Mg}\right.$, $\mathrm{HNO}_{3}, \mathrm{HCl}, \mathrm{H}_{2} \mathrm{SO}_{4}$ ), and the relative humidity and ambient temperature. The mechanism of the course of chemical reactions, and a method of equilibrium calculation existing between the different substances was based on the $\mathrm{R} 1, \mathrm{R} 2$ and $\mathrm{R} 3$ ratios, describing the potential of sulphates formation depending on the qualitative and quantitative presence of precursors of their formation in the air. The R1 ratio was defined descriptively as the "total sulphate ratio", and is calculated as the ratio of the sum of the concentrations: $\mathrm{NH}_{3}, \mathrm{Na}, \mathrm{Ca}, \mathrm{K}, \mathrm{Mg}$ and $\mathrm{Na}$ in relation to $\mathrm{SO}_{4}{ }^{2-}$ concentration. The $\mathrm{R} 2$ ratio was defined descriptively, as the "crustal species and sodium ratio", and is calculated as the ratio of the sum of the concentrations: $\mathrm{Na}, \mathrm{Ca}, \mathrm{K}$ and $\mathrm{Mg}$ in relation to $\mathrm{SO}_{4}{ }^{2-}$ concentration. Whereas the $\mathrm{R} 3$ concentration was defined descriptively as the "crustal species ratio", and is calculated as the ratio of the sum of the concentrations: $\mathrm{Ca}, \mathrm{K}, \mathrm{Mg}$ in relation to $\mathrm{SO}_{4}{ }^{2-}$ concentration. On the basis of the value of the defined ratios, 5 paths of aerosol formation were specified, the products of which are different substances in different physical states. In the described mechanism the phase transition from solid to a saturated aqueous solution was determined on the basis of the matural deliquescence relative humidity (MDRH) parameter, which depends on the temperature. A method of determining the MDRH value is described in the work [52]. Research on the ISORROPIA 2.1 model implemented in CALPUFF v. 6.4 in the form of the ISORROPIA/RIVAD module (MCHEM = 6) demonstrated that this module generates from 3 to 10 times lower concentrations of nitrate in solid form as compared to the older version of the model used in CALPUFF [14]. This situation does not concern nitrate concentrations resulting in sub-zero temperatures $\left(-10^{\circ} \mathrm{C}\right)$. A significant drawback of this older version of the model was also the inclusion of the same background levels of ammonia $\left(\mathrm{NH}_{3}\right)$ in the air for many overlapping puffs. The same ammonia background was used for various puffs thus violating the law of mass preservation. This resulted in overestimation of modelled nitrate concentrations [13]. In order to correct this error in the CALPUFF v. 6.4 model, a post processing using the POSTUTIL subprogram was implemented [53].

The ISORROPIA/RIVAD+AQUA module (MAQCHEM = 1) takes into account, in addition to the ISORROPIA/RIVAD module (MAQCHEM $=0$ ), a new option of chemical 
transformations in the aqueous-phase implemented in the CALPUFF v. 6.4 model. Computational algorithms used in this option were adapted from RADM model, based on the mechanism of chemical transformations occurring in the aqueous-phase used in operating models such as CMAQ, CAMx or CMAQ-Madrid [13, 14, 53]. This mechanism takes into account the formation of sulphates on the basis of five chemical reactions, it also allows calculation of the $\mathrm{pH}$ value of which the kinetics of the course of some of these reactions depend. These reactions describe the oxidation processes of $\mathrm{SO}_{2}$ by $\mathrm{O}_{3}$ and $\mathrm{H}_{2} \mathrm{O}_{2}$, the catalytic oxidation of trace metals present in the air, and oxidation with organic peroxides or with peracetic acid. In the analysed mechanism only the first three reactions are included. In the oxidation reaction of $\mathrm{SO}_{2}$ with the help of $\mathrm{O}_{3}$, the $\mathrm{O}_{3}$ concentration is calculated by the RIVAD/ARM3 module. A similar solution is used to adjust the concentration of $\mathrm{H}_{2} \mathrm{O}_{2}$ under the second reaction taking place in the aqueous-phase. The $\mathrm{SO}_{2}+\mathrm{H}_{2} \mathrm{O}_{2}$ reaction taking place in the aqueous-phase is very rapid and is usually limited by the presence of $\mathrm{H}_{2} \mathrm{O}_{2}$ in the air. Hence $\mathrm{H}_{2} \mathrm{O}_{2}$ concentration in the modelled puff is decreasing very fast to ultimately - in the absence of the source of $\mathrm{H}_{2} \mathrm{O}_{2}$ occurrence in the air - reach a very low or zero level. In the third oxidation reaction $\mathrm{SO}_{2}$ takes into account the typical background concentration of trace metals (Fe and $\mathrm{Mn})$ in the air $[13,14,53]$.

\section{Results and discussion}

Table 2 shows the highest values of the maximum 1-hour and 24-hour average concentrations in the air of substances under consideration obtained in the accepted calculation area for individual variants. Table 3 shows the results of calculations for maximum and average area values of average annual concentrations.

According to the data summarized in Tables 2 and 3, the highest values of maximum 1-hour and 24-hour average concentrations, and annual average of all primary pollutants were obtained at a level similar for the V1, V2, V3 and V4 variants, and in the case of PPM (PM10) and $\mathrm{NO}_{\mathrm{x}}$ - also for the V5 variant. It should be noted, that these maximums for individual substances may have been present at various points of the calculation area, and in the case of short-term concentrations also at different times which stems among others from the variability in emissions of primary pollutants, and parameters of flue gases in the analysed period.

In principle the type of chemical transformation module used does not significantly affect the obtained calculation results of the maximum and mean values of $\mathrm{NO}$ and $\mathrm{NO}_{2}$ concentrations in air, and their total concentration $\left(\mathrm{NO}_{\mathrm{x}}\right)$ is obtained at a level that is not much lower compared to modelling results carried out without taking into account chemical transformations. The most reliable in this respect were the results obtained for variants V3, V4 and V5. This chemical transformation modules included in these options take into account the correction of error occurring in the MESOPUFF module (variant V2). This error caused revaluation of nitrates formed during $\mathrm{NO}_{\mathrm{x}}$ oxidation.

The use of the ISORROPIA/RIVAD+AQUA module in the process of atmospheric dispersion modelling (variant V5) caused the greatest divergence in relation to other variants in the case of calculation results of average annual concentration of PM10, and maximum 1-hour, and annual average $\mathrm{SO}_{2}$ concentrations. The chemical transformations module in the aqueous-phase implemented in CALPUFF model (version 6.42) intensifies the process of $\mathrm{SO}_{2}$ conversion into sulphate forms. Disregarding this effect in the process of atmospheric dispersion modelling, it still contributes to the overestimation of calculation 
results of $\mathrm{SO}_{2}$ concentrations (to varying degrees depending on the time averaging), and significant underestimation of the level of average annual concentration of PM10 in the air.

Table 2

The highest values of maximum 1-hour and 24-hour average concentrations in the air, obtained within the assumed computational area for particular variants

\begin{tabular}{|c|c|c|c|c|c|c|c|c|c|c|}
\hline \multirow[t]{2}{*}{ Air pollutant } & \multicolumn{5}{|c|}{$\begin{array}{l}\text { The highest 1-hour average concentration } \\
\text { in the variant }\left[\mathrm{\mu g} \mathrm{m}^{-3}\right]\end{array}$} & \multicolumn{5}{|c|}{$\begin{array}{l}\text { The highest 24-hour average concentration } \\
\text { in the variant }\left[\mu \mathrm{g} \mathrm{m}^{-3}\right]\end{array}$} \\
\hline & V1 & V2 & V3 & $\mathrm{V4}$ & V5 & V1 & V2 & V3 & V4 & V5 \\
\hline $\mathrm{NO}$ & - & - & 53.6 & 62.4 & 62.4 & - & - & 3.27 & 3.28 & 3.28 \\
\hline $\mathrm{NO}_{2}$ & - & - & 165.8 & 162.7 & 162.6 & - & - & 20.51 & 20.50 & 20.50 \\
\hline $\mathrm{NO}_{\mathrm{x}}{ }^{*}$ & 241.3 & 230.1 & 240.3 & 240.1 & 240.1 & 21.62 & 21.57 & 21.60 & 21.60 & 21.60 \\
\hline $\mathrm{SO}_{2}$ & 582.1 & 576.8 & 581.1 & 581.2 & 491.3 & 34.09 & 33.72 & 34.01 & 34.03 & 33.22 \\
\hline PPM (PM10) & 449.1 & 449.1 & 449.1 & 449.1 & 449.1 & 29.09 & 29.09 & 29.09 & 29.09 & 29.09 \\
\hline SIA $\left(\mathrm{NO}_{3}^{-}\right)$ & - & 7.0 & 4.6 & 5.3 & 5.3 & - & 0.47 & 0.25 & 0.28 & 0.28 \\
\hline SIA $\left(\mathrm{SO}_{4}^{2-}\right)$ & - & 13.3 & 3.2 & 2.5 & 264.6 & - & 0.78 & 0.21 & 0.16 & 23.66 \\
\hline SIA (total) & - & 20.3 & 5.6 & 5.7 & 264.6 & - & 1.18 & 0.36 & 0.33 & 23.66 \\
\hline $\begin{array}{l}\text { PPM+SIA } \\
\text { (total) }\end{array}$ & 449.1 & 449.3 & 449.1 & 449.1 & 466.4 & 29.09 & 29.11 & 29.10 & 29.10 & 31.87 \\
\hline
\end{tabular}

* expressed as $\mathrm{NO}_{2}$

Table 3

The highest and mean values of annual average concentrations in the air, obtained within the assumed computational area for particular variants

\begin{tabular}{|c|c|c|c|c|c|c|c|c|c|c|}
\hline \multirow[t]{2}{*}{ Air pollutant } & \multicolumn{5}{|c|}{$\begin{array}{c}\text { The highest annual average concentration } \\
\text { in the variant }\left[\mu \mathrm{g} \mathrm{m}^{-3}\right]\end{array}$} & \multicolumn{5}{|c|}{$\begin{array}{l}\text { The mean of annual average concentrations } \\
\text { in the variant }\left[\mu \mathrm{g} \mathrm{m}^{-3}\right]\end{array}$} \\
\hline & V1 & V2 & $\mathbf{V 3}$ & V4 & V5 & V1 & V2 & V3 & V4 & V5 \\
\hline $\mathrm{NO}$ & - & - & 0.369 & 0.371 & 0.371 & - & - & 0.024 & 0.025 & 0.025 \\
\hline $\mathrm{NO}_{2}$ & - & - & 1.443 & 1.438 & 1.439 & - & - & 0.198 & 0.196 & 0.196 \\
\hline $\mathrm{NO}_{\mathrm{x}}{ }^{*}$ & 1.999 & 1.980 & 1.993 & 1.992 & 1.993 & 0.240 & 0.222 & 0.235 & 0.234 & 0.234 \\
\hline $\mathrm{SO}_{2}$ & 3.108 & 3.104 & 3.106 & 3.104 & 2.610 & 0.363 & 0.360 & 0.361 & 0.361 & 0.172 \\
\hline PPM (PM10) & 0.307 & 0.307 & 0.307 & 0.307 & 0.307 & 0.028 & 0.028 & 0.028 & 0.028 & 0.028 \\
\hline $\mathrm{SIA}\left(\mathrm{NO}_{3}{ }^{-}\right)$ & - & 0.019 & 0.010 & 0.005 & 0.005 & - & 0.006 & 0.003 & 0.001 & 0.001 \\
\hline SIA $\left(\mathrm{SO}_{4}{ }^{2-}\right)$ & - & 0.013 & 0.008 & 0.006 & 1.955 & & 0.005 & 0.003 & 0.002 & 0.250 \\
\hline SIA (total) & - & 0.031 & 0.017 & 0.011 & 1.956 & - & 0.011 & 0.006 & 0.003 & 0.251 \\
\hline $\begin{array}{c}\begin{array}{c}\text { PPM+SIA } \\
\text { (total) }\end{array} \\
\end{array}$ & 0.307 & 0.320 & 0.313 & 0.310 & 2.130 & 0.028 & 0.039 & 0.034 & 0.032 & 0.279 \\
\hline
\end{tabular}

* expressed as $\mathrm{NO}_{2}$

In case of $\mathrm{SO}_{2}$ in variants $\mathrm{V} 1-\mathrm{V} 4$ compared to variant $\mathrm{V} 5$, the overestimation of the highest values from the maximum 1-hour, and annual average concentrations was obtained by about $17-19 \%$, maximum 24 -hour average concentrations by about $2 \%$, and the annual average concentrations in the modelling domain up to approx. $109-111 \%$. At the same time in variants V1-V4 we could observe from 7 to 10 times lower maximum and average annual area concentrations of PM10 compared to variant V5. The disproportion between the variants V1-V4 and V5 in terms of the highest values from the maximum 1-hour and 24-hour average concentrations of PM10 were already much lower, and amounted to approx. 4 and $9-10 \%$. To some extent this was due to inclusion in the calculation of atmospheric dispersion of the boiler start up phases (after a long downtime) characterized by a significant, several hours long increase in PM10 emissions in relation to the normal operation of the boiler, and resulting in episodes of momentary high concentrations of PM10 in the air with a small share of SIA. On the other hand, discrepancies obtained for the 
various variants in terms of mean concentrations of $\mathrm{SO}_{2}$ and $\mathrm{PM} 10$ in the air should be regarded as extreme due to the adoption of a relatively high $\mathrm{NH}_{3}$ background and disregarding its use in the reactions taking place with involvement of $\mathrm{SO}_{2}$ originating from other emission sources.

Figures 2 and 3 show spatial distributions of the average annual concentrations of PM10 in the air at ground level obtained for variants V1 (PPM) and V5 (PPM+SIA). These figures show that inclusion of the ISORROPIA/RIVAD+AQUA chemical transformation module resulted not only in significant increase in the average annual concentrations achieved in the results of PM10 atmospheric dispersion modelling but also change of the position of the maximum values of these concentrations.

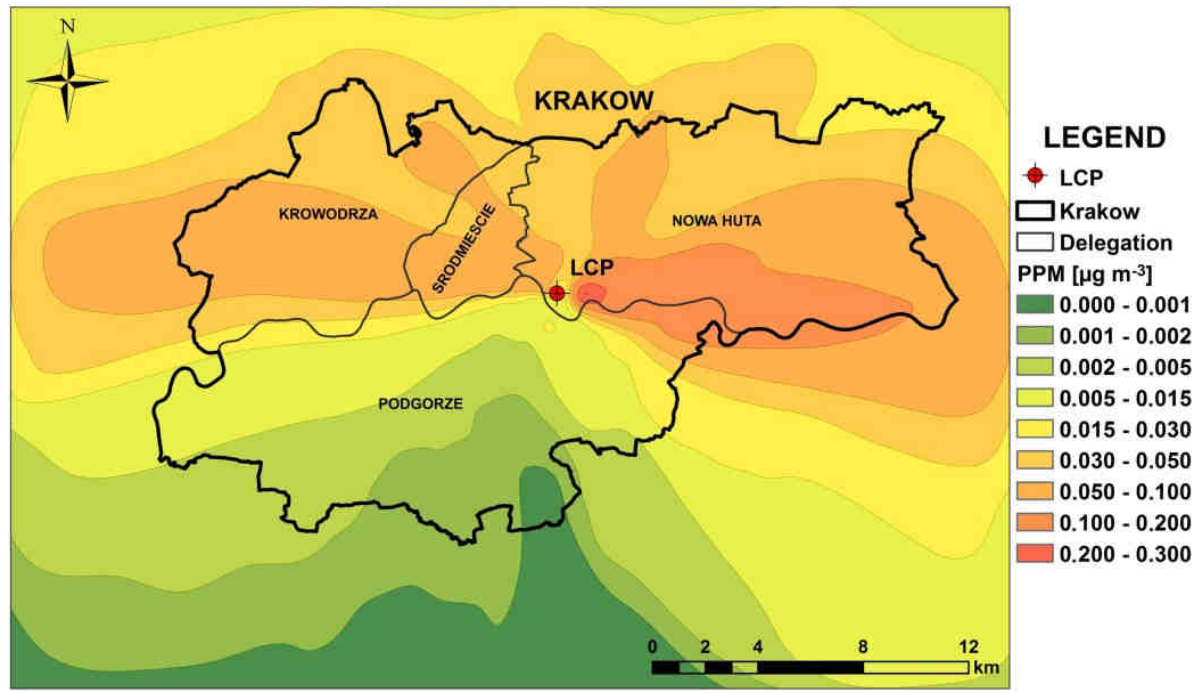

Fig. 2. Spatial distribution of annual average PM10 (PPM) concentrations in the air obtained for the variant V1 (calculations excluding chemical transformation modules)

The average shares of secondary nitrate and sulfate aerosols in a total concentration of SIA and in relation to the average concentration of PM10 (PPM+SIA) obtained for the various variants of calculations in computing receptors grid are given in Table 4 . The observed increase in the average annual concentration of PM10 in air in variant V5 is therefore due primarily to the intensification of the formation of secondary aerosol sulfate in the aqueous-phase taken into account in the ISORROPIA/RIVAD+AQUA module. In the case of average-area annual average concentrations in this variant, the sulfate secondary aerosol represented approx. $99.2 \%$ of total SIA mass, and approx. $89.4 \%$ relative to the sum of the PPM and total SIA masses. A similar share of secondary nitrate aerosol was much lower and amounted to $0.8 \%$ of SIA, and $0.7 \%$ of PPM+SIA respectively. It should also be noted that in the variants V4 and V5 associated with use of the ISORROPIA 2.1 model, a significant reduction in the annual average concentrations of secondary nitrate aerosols was obtained in comparison to variants V2 and V3. This is due to the elimination in the ISORROPIA/RIVAD module of the phenomenon of overestimating their concentrations typical for MESOPUFF (variant V2) and RIVAD/ARM3 (variant V3) modules [15]. 


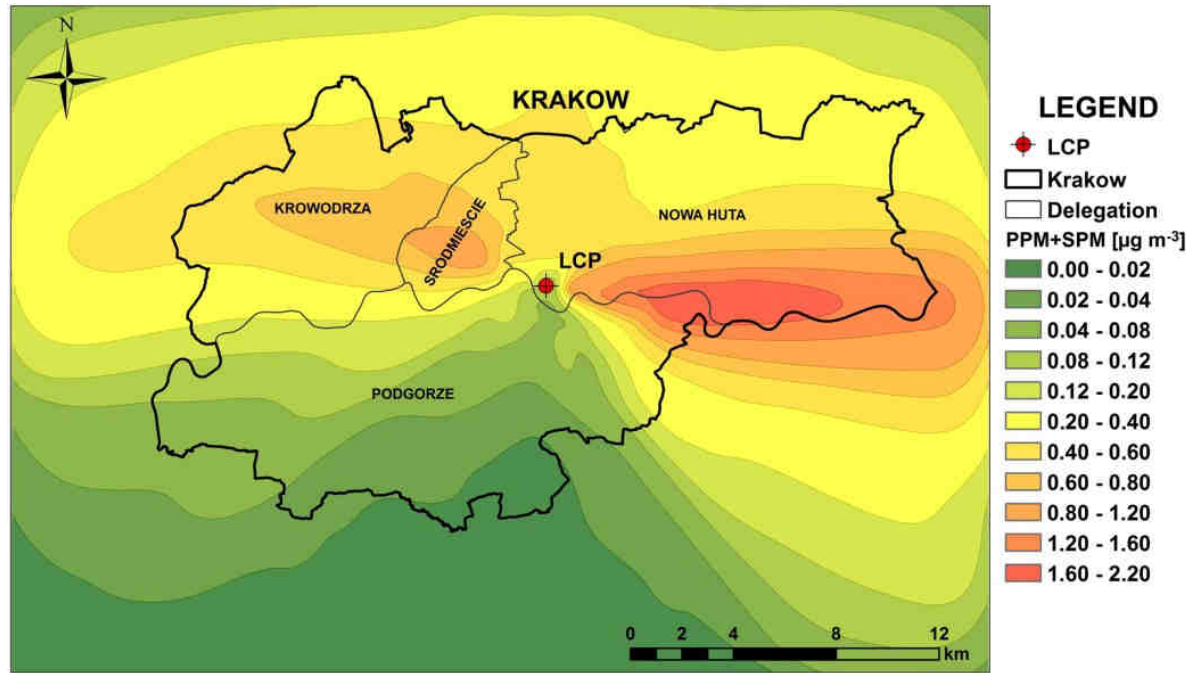

Fig. 3. Spatial distribution of annual average PM10 (PPM+SIA) concentrations in the air obtained for the variant V5 (calculations including the ISORROPIA/RIVAD+AQUA module)

Table 4 Average shares of the secondary nitrate and sulfate aerosols in SIA and PPM+SIA total concentrations obtained in the modelling domain for calculation variants including chemical transformation modules

\begin{tabular}{|c|c|c|c|c|c|c|c|c|}
\hline \multirow{2}{*}{$\begin{array}{c}\text { Aerosol } \\
\text { type }\end{array}$} & \multicolumn{4}{|c|}{ Average share in SIA [\%] } & \multicolumn{4}{c|}{ Average share in PPM+SIA [\%] } \\
\cline { 2 - 9 } & $\mathbf{V 2}$ & $\mathbf{V 3}$ & V4 & V5 & V2 & V3 & V4 & V5 \\
\hline SIA $\left(\mathrm{NO}_{3}{ }^{-}\right)$ & 55.6 & 50.5 & 29.8 & 0.8 & 21.4 & 13.0 & 5.3 & 0.7 \\
\hline SIA $\left(\mathrm{SO}_{4}{ }^{2-}\right)$ & 44.4 & 49.5 & 70.2 & 99.2 & 17.1 & 12.7 & 12.5 & 89.4 \\
\hline SIA (total) & 100.0 & 100.0 & 100.0 & 100.0 & 38.5 & 25.7 & 17.8 & 90.1 \\
\hline
\end{tabular}

The average share of secondary sulphate and nitrate aerosols in the area-average annual mean concentration of PM10 (as the sum of PPM and SIA) has reached in variant V5 the level of $90.1 \%$. Along with increasing distance from the analysed large combustion plant this share was slightly increasing relative to this average value, especially in the areas to the east and west of the analysed large combustion plant, i.e. along the dominant wind directions. Thus, the SIA formation should not be disregarded in assessing the impact on air quality especially in the case of those sources of emissions of which emissions of precursors of secondary inorganic aerosols $\left(\right.$ mainly $\left.\mathrm{SO}_{2}\right)$ is present at significant levels in relation to the PPM emissions.

This phenomenon is further illustrated in Figures 4 and 5, showing the results of modelling of annual average concentration of pollutants achieved for each calculation variant in location points of three selected air quality monitoring stations (Krakow - Nowa Huta, Krakow - Aleja Krasinskiego, and Niepolomice). The analysis of wind roses at computing altitudes from 20 to $160 \mathrm{~m}$ presented in the paper [38], and averaged for the Krakow region for the year 2012 leads to the conclusion that these stations during the analysed period remained under significant influence of emissions from the industrial plant in question. 


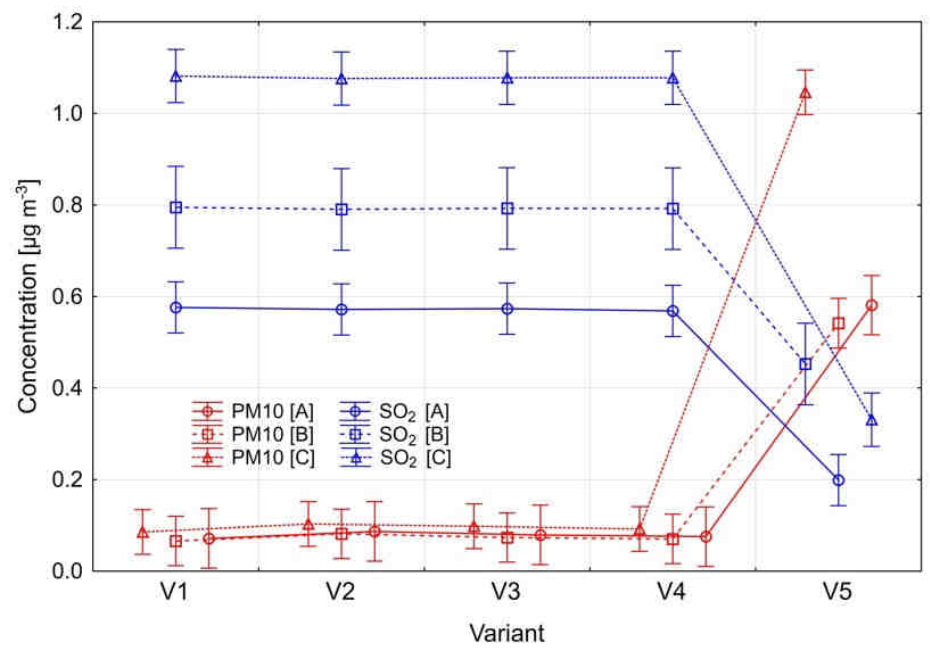

Fig. 4. Graphical presentation of the annual average $\mathrm{PM} 10$ and $\mathrm{SO}_{2}$ concentrations in air with 0.95-level confidence intervals received in the points of location of air quality monitoring stations for individual variants (A - Nowa Huta, B - Aleja Krasinskiego, C - Niepolomice)

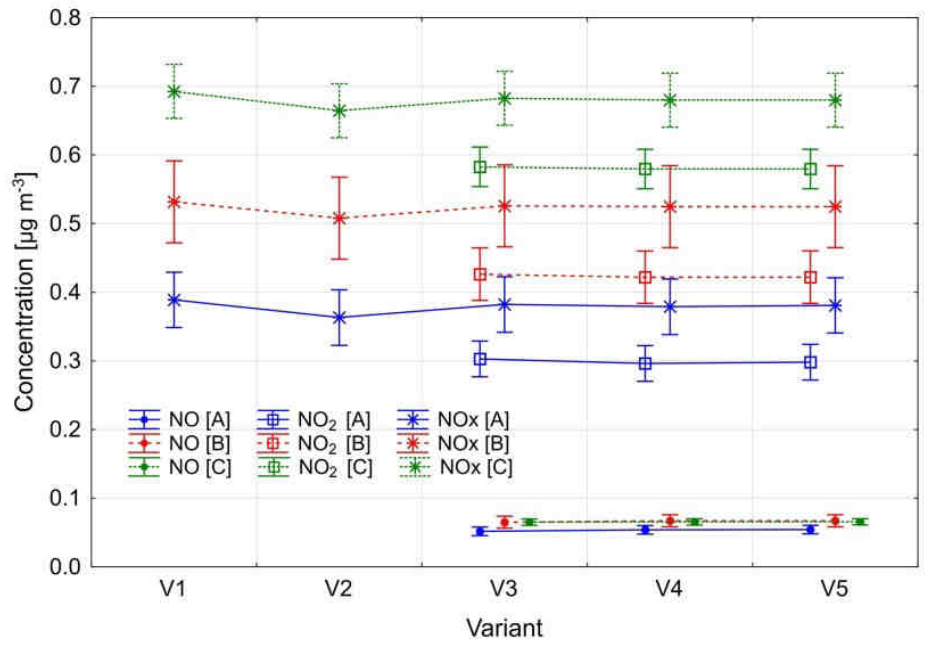

Fig. 5. Graphical presentation of the annual average $\mathrm{NO}, \mathrm{NO}_{2}$ and $\mathrm{NO}_{\mathrm{x}}$ concentrations in air with 0.95 -level confidence intervals received in the points of location of air quality monitoring stations for individual variants (A - Nowa Huta, B - Aleja Krasinskiego, C - Niepolomice)

Just as was the case in many other points of modelling domain for variant V5, a more intense formation in the air of secondary sulphate aerosol was obtained, resulting in a significant increase in the average annual concentration of PM10, and a decrease in annual average concentration of $\mathrm{SO}_{2}$ (Fig. 4). This effect was relatively best reflected in the case of the calculation point designated in the area of Niepolomice station located approx. 
$15 \mathrm{~km}$ east of the facility in question. In the case of average annual concentrations of NO, $\mathrm{NO}_{2}$, and $\mathrm{NO}_{\mathrm{x}}$ similar results were obtained for all analysed options (Fig. 5).

Table 5 shows the extreme impact of the CHP plant in question on the state of air pollution in the vicinity of the location of the above-mentioned air quality monitoring stations in the form of the modelled maximum 1-hour average concentrations of PM10 (PPM+SIA), $\mathrm{SO}_{2}$ and $\mathrm{NO}_{\mathrm{x}}$. This table also includes the results of calculations of these concentrations obtained for the two urban background monitoring stations (Krakow Kurdwanow, and Skawina), as well as selected results of measurements of maximum 1-hour concentrations, and annual average concentrations of various substances registered at all considered monitoring stations in analysed year.

Table 5

The maximum 1-hour average concentrations of $\mathrm{PM} 10, \mathrm{SO}_{2}$ and $\mathrm{NO}_{\mathrm{x}}$ in the air obtained for analyzed variants in points of location of air quality monitoring stations in relation to the results of measurements in 2012

\begin{tabular}{|c|c|c|c|c|c|c|c|c|}
\hline \multirow{2}{*}{ Air pollutant } & \multirow{2}{*}{$\begin{array}{l}\text { Location of the } \\
\text { calculation or } \\
\text { measurement } \\
\text { point }\end{array}$} & \multicolumn{5}{|c|}{$\begin{array}{l}\text { Modelling results of maximum 1-hour average } \\
\text { concentrations in the variant }\left[\mu \mathrm{g} \mathrm{m}^{-3}\right]\end{array}$} & \multicolumn{2}{|c|}{$\begin{array}{c}\text { Measurement results } \\
{\left[\mu \mathrm{g} \mathrm{m}^{-3}\right][41]}\end{array}$} \\
\hline & & V1 & $\mathbf{V} 2$ & V3 & V4 & V5 & $\begin{array}{l}\text { max. } \\
\text { 1-hour }\end{array}$ & $\begin{array}{l}\text { annual } \\
\text { average }\end{array}$ \\
\hline \multirow{5}{*}{ PM10 } & Kurdwanow & 2.12 & 2.91 & 2.32 & 2.30 & 28.09 & 469.0 & 52.0 \\
\hline & Nowa Huta & 185.90 & 186.06 & 185.98 & 185.93 & 219.08 & 448.0 & 54.8 \\
\hline & Krasinskiego & 117.48 & 117.64 & 117.52 & 117.50 & 145.04 & 531.0 & 65.9 \\
\hline & Niepolomice & 40.12 & 40.15 & 40.15 & 40.12 & 53.48 & 253.0 & 37.9 \\
\hline & Skawina & 1.31 & 2.23 & 1.85 & 1.96 & 25.92 & 488.0 & 54.0 \\
\hline \multirow{5}{*}{$\mathrm{SO}_{2}$} & Kurdwanow & 32.83 & 32.73 & 32.73 & 32.73 & 32.73 & 175.0 & 10.7 \\
\hline & Nowa Huta & 90.61 & 90.23 & 90.45 & 90.47 & 38.43 & 124.0 & 9.8 \\
\hline & Krasinskiego & 129.79 & 129.47 & 129.71 & 129.71 & 129.71 & 134.0 & 11.0 \\
\hline & Niepolomice & 34.99 & 34.97 & 34.97 & 34.97 & 30.78 & - & - \\
\hline & Skawina & 35.04 & 34.86 & 34.88 & 34.90 & 34.90 & 159.0 & 10.7 \\
\hline \multirow{5}{*}{$\begin{array}{c}\mathrm{NO}_{\mathrm{x}} \\
\left(\mathrm{NO}+\mathrm{NO}_{2}\right)\end{array}$} & Kurdwanow & 16.81 & 16.33 & 16.77 & 16.78 & 16.78 & 950.0 & 83.6 \\
\hline & Nowa Huta & 50.46 & 47.66 & 50.27 & 50.20 & 50.16 & 682.0 & 60.7 \\
\hline & Krasinskiego & 75.93 & 75.80 & 75.90 & 75.89 & 75.89 & 1335.0 & 231.5 \\
\hline & Niepolomice & 18.31 & 18.16 & 18.25 & 18.25 & 18.25 & - & - \\
\hline & Skawina & 16.98 & 14.97 & 16.76 & 16.62 & 16.62 & 589.0 & 36.6 \\
\hline
\end{tabular}

The results of calculations presented in Table 5 indicate that at the location point of air quality monitoring station Krakow - Kurdwanow and Skawina as a result of modelling a very low maximum 1-hour concentrations of dust PM10 were obtained in variants V1 (only PPM) and V2, V3 and V4 (PPM+SIA). By contrast, included in variant V5 was the mechanism of secondary sulphate aerosol formation in the aqueous-phase, which resulted in a significant increase in the maximum 1-hour average PM10 concentration in the air calculated in the area of these stations in relation to the results obtained in other variants (10 to 20 times, depending on the reference variant). For the calculation points located in the vicinity of location of Nowa Huta, Aleja Krasinskiego, and Niepolomice stations, already much smaller increase in the maximum 1-hour average PM10 concentration in variant V5 was obtained in relation to other variants (by approx. 18, 23, and 33\% respectively). In turn a certain reduction in maximum 1-hour average $\mathrm{SO}_{2}$ concentrations in variant V5 has occurred only for Krakow - Nowa Huta and Niepolomice points. No significant changes in the results of calculations of maximum 1-hour average $\mathrm{NO}_{\mathrm{x}}$ concentrations in the air after taking into account the chemical transformation modules 
were observed at calculation points designated in the vicinity of the monitoring station locations.

\section{Conclusions}

The evaluation of the impact on air quality of a group of emission sources through the use of the advanced CALPUFF models of atmospheric dispersion can be carried out with or without taking into account the modules of chemical transformation of pollutants in ambient air. The application of these modules requires the introduction of additional data as a $\mathrm{NH}_{3}, \mathrm{H}_{2} \mathrm{O}_{2}$, and $\mathrm{O}_{3}$ background in the air (preferably at the highest spatial and temporal resolution), and such data are not always available for the given modelling domain, and their possible designation using photochemical models is time consuming and can be highly biased.

In the CALPUFF version of the model used in this work (v. 6.42), modules have been implemented allowing for good reflection of the mechanism of secondary inorganic aerosol formation under thermodynamic equilibrium conditions, and chemical transformations occurring in the aqueous-phase. These types of modules are used in many of contemporary air quality forecasting models, e.g. CMAQ, CAMx or CMAQ-Madrid. However, depending on the choice of chemical transformation modules available in the CALPUFF model, it is possible to obtain different results of atmospheric dispersion modelling especially in terms of PM10 and $\mathrm{SO}_{2}$ concentrations in the air.

In calculations of the spread of pollutants in the air by CALPUFF model v. 6.42 performed for emission sources that emit large quantities of $\mathrm{SO}_{2}$ it is recommended to use ISORROPIA/RIVAD+AQUA chemical transformation module (MCHEM $=6$, MAQCHEM = 1). It is clear from these type of calculations carried out for the coal-fired CHP plant not equipped with FGD system (with annual emissions of particulate matter, $\mathrm{SO}_{2}$, and $\mathrm{NO}_{\mathrm{x}}$ remaining in analysed period in a ratio of 1:9:6), the use of this module significantly increased PM10 concentrations (including SIA), and decreased $\mathrm{SO}_{2}$ concentrations in modelling domain as compared to computing variants based on other available modules of chemical transformations, and the variant disregarding chemical transformations. The scope of these changes was strongly dependent on the position of the computing receptor in relation to the emission sources (distance, wind rose sector), and the type of concentration (averaging time). Maximum disparity was obtained for annual average concentrations, and in some points also for the maximum 1-hour average concentration of PM10. In extreme cases disregarding chemical transformations modules resulted in up to 20-fold underestimation of the calculation results of these concentrations compared to the option in which the ISORROPIA/RIVAD+AQUA module was used. A significant impact on the calculated concentrations of $\mathrm{SO}_{2}$ and PM10 in the air has a mechanism of formation of secondary sulphate aerosols in the aqueous-phase included in the above mention module. The use of this module in atmospheric dispersion modelling of pollutants, emitted from the analysed large combustion plant, caused the average (for the modelling domain) content of SIA in PM10 amounts to approx. 90.1\%, and the secondary sulphate aerosol alone to approx. $89.4 \%$.

The selection of chemical transformations module does not greatly affect the results of modelling of $\mathrm{NO}, \mathrm{NO}_{2}$, and $\mathrm{NO}_{\mathrm{x}}$ concentrations in the air. However, the use of modules based on the ISORROPIA 2.1 model $($ MCHEM = 6) allows for elimination of the 
phenomenon of certain overestimation of secondary nitrate aerosol concentration typical for inter alia MESOPUFF (MCHEM = 1) and RIVAD/ARM3 modules (MCHEM = 3).

If the modelling of atmospheric dispersion of pollutants emitted from large combustion plants is carried out without regard to chemical transformations leading to the formation of secondary inorganic aerosols, it can lead to erroneous conclusions in terms of the assessment of the impact on air quality of the given plant (especially in the case of high $\mathrm{SO}_{2}$ emission). The analysis of discrepancies obtained in this regard requires further study taking into account the variability of emissions of fine particulate matter, $\mathrm{SO}_{2}$, and $\mathrm{NO}_{\mathrm{x}}$ and background air concentrations of $\mathrm{NH}_{3}, \mathrm{H}_{2} \mathrm{O}_{2}$, and $\mathrm{O}_{3}$.

\section{Acknowledgments}

The paper has been prepared within the scope of the AGH UST statutory research no. 11.11.150.008. We thank Izabela Sowka for providing us the results of $\mathrm{H}_{2} \mathrm{O}_{2}$ air concentrations from a measurement campaign conducted in Wroclaw.

\section{References}

[1] Hanna SR, Schulman LL, Paine RJ, Pleim JE, Baer M. Development and evaluation of the offshore and coastal dispersion model. J Air Pollut Control Assoc. 1985;35(10):1039-1047. DOI: 10.1080/00022470.1985.10466003.

[2] Steven PG. CTDMPLUS: A Dispersion model for sources near complex topography. Part I: Technical formulations. J Appl Meteorol. 1992;31(7):633-645. DOI: 10.1175/1520-0450(1992)031<0633:CADMFS>2.0.CO;2.

[3] Paumier JO, Burns DJ, Perry SG. CTDMPLUS: A dispersion model for sources near complex topography. Part II: Performance characteristics. J Appl Meteorol. 1992;31(7):646-660. DOI: 10.1175/1520-0450(1992)031<0646:CADMFS>2.0.CO;2.

[4] US EPA. User's guide for the Industrial Source Complex (ISC3) Dispersion Models: Volume II Description of Model Algorithms. Tech. Rep. EPA-454/B-95-003b. Office of Air Quality Planning and Standards Emissions, Monitoring and Analysis Division, Research Triangle Park, NC; 1995. https://www.epa.gov/scram001/userg/regmod/isc3v2.pdf.

[5] Janicke U, Janicke L. Lagrangian particle modelling for regulatory purposes - a survey of recent developments in Germany. 11th International Conference on Harmonisation within Atmospheric Dispersion Modelling for Regulatory Purposes. 2004:109-113. http://www.harmo.org/conferences/proceedings/ _Cambridge/publishedSections/Op109-113.pdf.

[6] Cimorelli AJ, Perry SG, Venkatram A, Weil JC, Paine RJ, Wilson RB, et al. AERMOD: A dispersion model for industrial source applications. Part I: General model formulation and boundary layer characterization. J Appl Meteorol. 2005;44(5):682-693. DOI: 10.1175/JAM2227.1.

[7] Perry SG, Cimorelli AJ, Paine RJ, Brode RW, Weil JC, Venkatram A, et al. AERMOD: A dispersion model for industrial source applications. Part II: Model performance against 17 field study databases. J Appl Meteorol. 2005;44(5):694-708. DOI: 10.1175/JAM2228.1.

[8] Helge Rørdam Olesen PL, Berkowicz R. OML: Review of model formulation. NERI Technical Report No. 609; 2007. http://www.dmu.dk/Pub/FR609.pdf.

[9] CERC. ADMS 5.0 Flat Terrain Validation Kincaid, Indianapolis and Prairie Grass. June 2013. http://www.cerc.co.uk/environmental-software/assets/data/doc_validation/CERC_ADMS5_Study_ Validation_Kincaid_Indianapolis_PrairieGrass_5.0_vs_4.2.pdf.

[10] Holmes NS, Morawska L. A review of dispersion modelling and its application to the dispersion of particles: An overview of different dispersion models available. Atmos Environ. 2006;40:5902-5928. DOI: 10.1016/j.atmosenv.2006.06.003.

[11] Scire JS, Robe FR, Fernau ME, Yamartino RJ. A user's guide for the CALMET meteorological model (Version 5). Earth Tech, Inc. Concord, MA; 2000. http://www.src.com/calpuff/download/ CALMET_UsersGuide.pdf.

[12] Scire JS, Strimaitis DG, Yamartino RJ. A user's guide for the CALPUFF dispersion model (Version 5). Earth Tech, Inc. Concord, MA; 2000. http://www.src.com/calpuff/download/CALPUFF_UsersGuide.pdf. 
[13] Karamchandani P, Chen S, Seigneur C. CALPUFF Chemistry Upgrade. AER Final Report CP277-07-01 prepared for API, Washington, DC. San Ramon, CA; Atmospheric \& Environmental Research, Inc.; 2008. https://www3.epa.gov/ttn/scram/11thmodconf/200802-CALPUFF_Chemistry_Upgrade.pdf.

[14] Karamchandani P, Chen S-Y, Balmori R. Evaluation of original and improved versions of CALPUFF using the 1995 SWWYTAF data base. AER Report CP281-09-01 prepared for API, Washington, DC. San Francisco, CA: Atmospheric and Environmental Research, Inc.; 2009. http://mycommittees.api.org/rasa/amp/CALPUFF\%20Projects\%20and\%20Studies/CALPUFF\%20Evaluatio n\%20with\%20SWWYTAF,\%202009,\%20Kharamchandani\%20et\%20al.pdf.

[15] Scire JS, Strimaitis DG, Wu Z-X. New developments and evaluations of the CALPUFF model exponent. 10th EPA Conference on Air Quality Modeling. Research Triangle Park, NC; March 2012. http://mycommittees.api.org/rasa/amp/CALPUFF\%20Projects\%20and\%20Studies/CALPUFF\%20Evaluatio n\%20with\%20SWWYTAF,\%202009,\%20Kharamchandani\%20et\%20al.pdf.

[16] Suppan P, Skouloudis A. Inter-comparison of two air quality modelling systems for a case study in Berlin. Int J Environ Pollut. 2003;20:75-84. DOI: 10.1504/IJEP.2003.004250.

[17] Juda-Rezler K. New challenges in air quality and climate modeling. Archiv Environ Protect. 2010;36(1):3-28. www.ipis.zabrze.pl/dokumenty/archives/roczniki/2010/AOS10-1.pdf.

[18] Karamchandani P, Vijayaraghavan K, Yarwood G. Sub-grid scale plume modeling. Atmosphere. 2011;2(3):389-406. DOI: 10.3390/atmos2030389.

[19] Leelőssy Á, Molnár F, Izsák F, Havasi Á, Lagzi I, Mészáros R. Dispersion modeling of air pollutants in the atmosphere: a review. Open Geosciences. 2014;6(3):257-278. DOI: 10.2478/s13533-012-0188-6.

[20] US EPA. Guideline on Air Quality Models: Revision to the Guideline on Air Quality Models: Adoption of a Preferred General Purpose (Flat and Complex Terrain) Dispersion Model and Other Revisions; Final Rule. Federal Register, 40 CFR Part 51. 2005;70(216):68218-68261. https://www3.epa.gov/scram001/ guidance/guide/appw_05.pdf.

[21] US EPA. Clarification of regulatory status of CALPUFF for near-field applications. Office of Air Quality Planning and Standards, Air Quality Assessment Division, Research Triangle Park, NC; 2008. https://www3.epa.gov/scram001/guidance/clarification/clarification\%20of\%20regulatory\%20status\%20of\% 20calpuff.pdf.

[22] Levy JI, Spengler JD, Hlinka D, Sullivan D, Moon D. Using CALPUFF to evaluate the impacts of power plant emissions in Illinois: model sensitivity and implications. Atmos Environ. 2002;36:1063-1075. DOI: 10.1016/S1352-2310(01)00493-9.

[23] Levy JI, Wilson AM, Evans JS, Spengler JD. Estimation of primary and secondary particulate matter intake fractions for power plants in Georgia. Environ Sci Technol. 2003;37(24):5528-36. DOI: 10.1021/es0344841.

[24] Yim SHL, Fung JCH, Lau AKH. Use of high-resolution MM5/CALMET/CALPUFF system: $\mathrm{SO}_{2}$ apportionment to air quality in Hong Kong. Atmos Environ. 2010;44:4850-4858. DOI: 10.1016/j.atmosenv.2010.08.037.

[25] Cui H, Yao R, Xu X, Xin C, Yang J. A tracer experiment study to evaluate the CALPUFF real time application in a near-field complex terrain setting. Atmos Environ. 2011;45(39):7525-7532. DOI: 10.1016/j.atmosenv.2011.08.041.

[26] Hernández-Garces A, Souto Ja, Rodríguez Á, Saavedra S, Casares JJ. Validation of CALMET/CALPUFF models simulations around a large power plant stack. Física de la Tierra. 2015;27:35-55. DOI: http://dx.doi.org/10.5209/rev_FITE.2015.v27.51192.

[27] Dresser AL, Huizer RD. CALPUFF and AERMOD model validation study in the near field: Martins Creek revisited. J Air Waste Manage Assoc. 2011;61(6):647-659. DOI: 10.3155/1047-3289.61.6.647.

[28] Gulia S, Kumar A, Khare M. Performance evaluation of CALPUFF and AERMOD dispersion models for air quality assessment of an industrial complex. J Sci Ind Res. 2015;74:302-307. http://nopr.niscair.res.in/handle/123456789/31451.

[29] Jittra N, Pinthong N, Thepanondh S. Performance evaluation of AERMOD and CALPUFF air dispersion models in industrial complex area. Air Soil Water Res. 2015;8:87-95. DOI:10.4137/ASWR.S32781.

[30] Rood AS. Performance evaluation of AERMOD, CALPUFF, and legacy air dispersion models using the Winter Validation Tracer Study dataset. Atmos Environ. 2014;89:707-720. DOI: 10.1016/j.atmosenv.2014.02.054.

[31] Tartakovsky D, Broday DM, Stern E. Evaluation of AERMOD and CALPUFF for predicting ambient concentrations of total suspended particulate matter (TSP) emissions from a quarry in complex terrain. Environ Pollut. 2013;179:138-145. DOI: 10.1016/j.envpol.2013.04.023.

[32] Thepanondh S, Outapa P, Saikomol S. Evaluation of dispersion model performance in predicting $\mathrm{SO}_{2}$ concentrations from petroleum refinery complex. Int J GEOMATE. 2016;11(23):2129-2135. http://www.geomatejournal.com/sites/default/files/articles/2129-2135-1118-Thepanondh-July-2016-c1.pdf. 
[33] Holnicki P, Kałuszko A, Trapp W. An urban scale application and validation of the CALPUFF model. Atmos Pollut Res. 2015;7(3):393-402. DOI: 10.1016/j.apr.2015.10.016.

[34] Zhou Y, Levy JI, Hammitt JK, Evans JS. Estimating population exposure to power plant emissions using CALPUFF: a case study in Beijing, China. Atmos Environ. 2003;37(6):815-826. DOI: 10.1016/S1352-2310(02)00937-8.

[35] López MT, Zuk M, Garibay V, Tzintzun G, Iniestra R, Fernández A. Health impacts from power plant emissions in Mexico. Atmos Environ. 2005;39(7):1199-1209. DOI: 10.1016/j.atmosenv.2004.10.035.

[36] Hao J, Wang L, Shen M, Li L, Hu J. Air quality impacts of power plant emissions in Beijing. Environ Pollut. 2007;147:401-408. DOI: 10.1016/j.envpol.2006.06.013.

[37] ENVIRON International Corporation. Evaluation of Chemical Dispersion Models using Atmospheric Plume Measurements from Field Experiments. Final Report UNC-EMAQ 4-06.018.v4 prepared for Office of Air Quality Planning and Standards U.S. EPA. EPA Contract No: EP-D-07-102, Novato, CA; September 2012. https://www3.epa.gov/scram001/reports/Plume_Eval_Final_Sep_2012v5.pdf.

[38] Apostoł M, Bąkowski A, Chronowska-Przywara K, Kot M, Monieta J, Oleniacz R, et al. Wybrane zagadnienia inżynierii mechanicznej, materiałowej i środowiskowej (Selected issues of mechanical, material and environmental engineering). Kraków: Wyd. Katedra Automatyzacji Procesów, AGH w Krakowie; 2015. DOI: 10.13140/RG.2.1.2907.1440.

[39] EEA. Reported data on large combustion plants covered by Directive 2001/80/EC. August 2016. http://www.eea.europa.eu/data-and-maps/data/lcp-1.

[40] US EPA. AP42 Fifth Ed. Vol. 1, 1.1, 1993. http://www.epa.gov/ttn/chief/ap42/ch01/bgdocs/b01s01.pdf.

[41] Chief Inspectorate for Environmental Protection (Poland). Air Quality Portal. http://powietrze.gios.gov.pl (accessed in 31.01.2016).

[42] EEA. AirBase - The European air quality database. http://www.eea.europa.eu/data-and-maps/data/airbasethe-european-air-quality-database-8/ (accessed in 30.09.2015).

[43] EEA. Air Quality e-Reporting (AQ e-Reporting). May 2016. http://www.eea.europa.eu/data-andmaps/data/aqereporting-1.

[44] Oleniacz R, Rzeszutek M. Determination of optimal spatial databases for the area of Poland to the calculation of air pollutant dispersion using the CALMET/CALPUFF model. Geomat Environ Eng. 2014;8(2):57-69. DOI: 10.7494/geom.2014.8.2.57.

[45] Oleniacz R, Rzeszutek M. Assessment of the impact of spatial data on the results of air pollution dispersion modeling. Geoinformatica Polonica. 2014;13:57-68. DOI: 10.2478/gein-2014-0006.

[46] Stelson AW, Seinfeld JH. Relative humidity and temperature dependence of the ammonium nitrate dissociation constant. Atmospheric Environ. 1982;16:983-992. DOI: 10.1016/0004-6981(82)90184-6.

[47] Atkinson R, Lloyd AC, Winges L. An updated chemical mechanism for hydrocarbon/ $\mathrm{NO}_{\mathrm{x}} / \mathrm{SO}_{\mathrm{x}} \mathrm{photo}$ oxidation suitable for inclusion in atmospheric simulation models. Atmos Environ. 1982,16:1341-1355. DOI: 10.1016/0004-6981(82)90055-5.

[48] Scire JS, Lurmann FW, Bass A, Hanna SR. Development of the MESOPUFF II Dispersion Model. Concord, MA: Environmental Research and Technology, Inc.; Contract No. 68-02-3733; Environmental Sciences Research Lab., Office of Research and Development, U.S. EPA, Research Triangle Park, NC; 1984. https://nepis.epa.gov/Exe/ZyPDF.cgi/9101QF22.PDF?Dockey=9101QF22.PDF.

[49] Morris RE, Kessler RC, Douglas SG, Styles KR, Moore GE. Rocky Mountain Acid Deposition Model Assessment: Acid Rain Mountain Mesoscale Model (ARM3). San Rafael, CA.: Systems Applications, Inc., US EPA, Research Triangle Park, NC, Atmospheric Sciences Research Laboratory; 1988. https://ntrl.ntis.gov/NTRL/dashboard/searchResults/titleDetail/PB89124408.xhtml.

[50] Nenes A, Pandis SN, Pilinis C. ISORROPIA: A new thermodynamic equilibrium model for multiphase multicomponent inorganic aerosols. Aquat Geochem. 1998;4(1):123-152. DOI: 10.1023/A:1009604003981.

[51] Fountoukis C, Nenes A. ISORROPIA II: a computationally efficient thermodynamic equilibrium model for $\mathrm{K}^{+}-\mathrm{Ca}^{2+}-\mathrm{Mg}^{2+}-\mathrm{NH}_{4}{ }^{+}-\mathrm{Na}^{+}-\mathrm{SO}_{4}{ }^{2-}-\mathrm{NO}_{3}{ }^{-}-\mathrm{Cl}^{-}-\mathrm{H}_{2} \mathrm{O}$ aerosols. Atmos Chem Phys. 2007;7(17):4639-4659. DOI: 10.5194/acp-7-4639-2007.

[52] Wexler AS, Seinfeld JH. Second-generation inorganic aerosol model. Atmos Environ. 1991;25A:2731-2748. DOI: 10.1016/0960-1686(91)90203-J.

[53] TRC Environmental Corporation. CALPUFF Chemistry Updates: User's Instructions for API Chemistry Options. Prepared for WEST Associates, Lowell, MA; 2010. http://www.src.com/calpuff/download/Mod64_Files/UsersInstructions_UpdatedChemistry.pdf. 